\title{
Masyarakat Baduy dan pengobatan tradisional berbasis tanaman ${ }^{1}$
}

\author{
R. CECEP EKA PERMANA
}

\begin{abstract}
A Baduy community in general is still bound by the traditional rules (pikukuh). One of the pikukuh said lojor teu meunang dipotong, pendek teu meunang disambung, which means "what is long might not be cut off, what is short might not be connected". The implicated meaning pikukuh is that which does not change something or anything, or does not accept what is available without increasing or reducing what is available. This also includes not to accept modern goods or goods made in factories. The inner struggle of Baduy Luar is between on the one hand trying to preserve the customs of theirs ancestors, but on the other hand trying to follow the development in modernity and in their environment. This is reflected in issues related to health. If a Baduy falls ill, the dilemma is to choose between modern medical treatment that increasingly is easily accessible with the consequence to violate the local tradition, or to use the traditional herbs of which the local knowledge is decreasing with the consequence that is more difficult to get this kind of therapy.

KEYWORDS

Pengetahuan tradisional (indigenous knowledge), kearifan lokal (local wisdom), pengobatan tradisional (traditional medication), Baduy.
\end{abstract}

Masyarakat Baduy merupakan salah satu masyarakat sederhana di Indonesia yang sekarang hidup bersahaja di wilayah Provinsi Banten. Secara umum mereka masih mempertahankan adat tradisonalnya dengan ketat. Pedoman hidup dalam perilaku mempertahankan adat mereka disebut pikukuh. Pikukuh dianggap bernilai religius dan berlandaskan kepada agama asli Baduy, yang disebutSunda Wiwitan. Ketaatan dalam menjalankan pikukuh

$1 \quad$ Artikel ini merupakan hasil penelitian Hibah Bersaing XV Tahun I Dikti 2007 dengan para peneliti: R. Cecep Eka Permana, S.S., M.Si. (Ketua), Dina Nawangningrum, M.Hum., dan Isman Pratama Nasution, M.Si. (anggota).

R. CECEP EKA PERMANA adalah pengajar pada Departemen Arkeologi, Fakultas Ilmu Pengetahuan Budaya, Universitas Indonesia. Program S3 diselesaikannya pada tahun 2008 dengan disertasi berjudul "Pola gambar tangan pada gua-gua prasejarah Pangkep-Maros, Sulawesi Selatan" di Universitas Indonesia. Karya tulisnya antara lain: Kesetaraan gender dalam inti jagad Baduy (2005, Jakarta: Wedatama Widya Sastra; cetakan pertama 2001) dan Tata ruang masyarakat Baduy (2006, Jakarta: Wedatama Widya Sastra). E-mail: cecep04@ui.ac.id.

(C) 2009 Fakultas Ilmu Pengetahuan Budaya, Universitas Indonesia 
serta ketaatan pada agama dan adat leluhur warisan nenek moyang terasa jelas dalam pelaksanaan berbagai upacara ritual (Permana 2006: 38-39).

Dalam dinamika budaya masyarakat Baduy, pikukuh itu relatif bertahan kuat pada masyarakat Baduy Dalam (tangtu), namun melonggar pada masyarakat Baduy Luar (panamping). Pergulatan batin masyarakat Baduy Luar ini menarik dikaji karena di satu sisi tetap berusaha mengikuti adat leluhur, tetapi di sisi lain berusaha mengikuti perkembangan zaman dan lingkungan. Dalam kaitannya dengan kesehatan, bila seseorang warga Baduy menderita sakit, mereka dihadapkan pada dilema antara menggunakan pengobatan "modern" yang aksesnya semakin mudah (berarti melanggar adat), dan pengobatan tradisional yang pengetahuannya semakin sirna (berarti kesulitan dalam pengobatan).

Masyarakat Baduy sejatinya masih memiliki pengetahuan dan kearifan lokal tentang pengobatan tradisional khususnya yang berbasis tanaman yang diwariskan secara turun-temurun lewat tradisi lisan, karena hingga kini tradisi tulis masih ditabukan. Permasalahannya adalah pengetahuan tentang pengobatan tradisional tersebut kini cenderung semakin menipis. Warga masyarakat yang mengetahui pengetahuan tersebut semakin terbatas. Tanamantanaman berkhasiat obat pun sering sulit didapat, karena semak belukar dan hutan belantara tempat selama ini diperoleh tanaman obat semakin menyusut akibat perluasan ladang dan pemukiman. Jika ada yang sakit dan memerlukan obat, semakin sulit untuk mencari dan mendapatkannya. Sementara itu, obat-obatan "pabrik" banyak tersedia di warung-warung dan Puskesmas di pinggiran perkampungan Baduy. Hanya saja mereka tetap ditabukan menggunakan barang "modern" tersebut oleh adat.

Penggalian pengetahuan dan kearifan lokal masyarakat Baduy tentang pengobatan tradisional berbasis tanaman dirasakan juga bermanfaatkarenaikutmendukung program pendataan khazanah nasional berupa sumber-sumber asli dan pengetahuan tradisional untuk melindungi hak-hak kepemilikan intelektual. Selain itu, diharapkan pula agar masyarakat Baduy bangkit dan mampu memberdayakan pengetahuan dan kearifan lokal yang ada dalam rangka mengatasi masalah kesehatan tanpa menimbulkan konflik batin terhadap adat.

Penelitian dalam tulisan ini dilakukan di Baduy Luar, yakni di

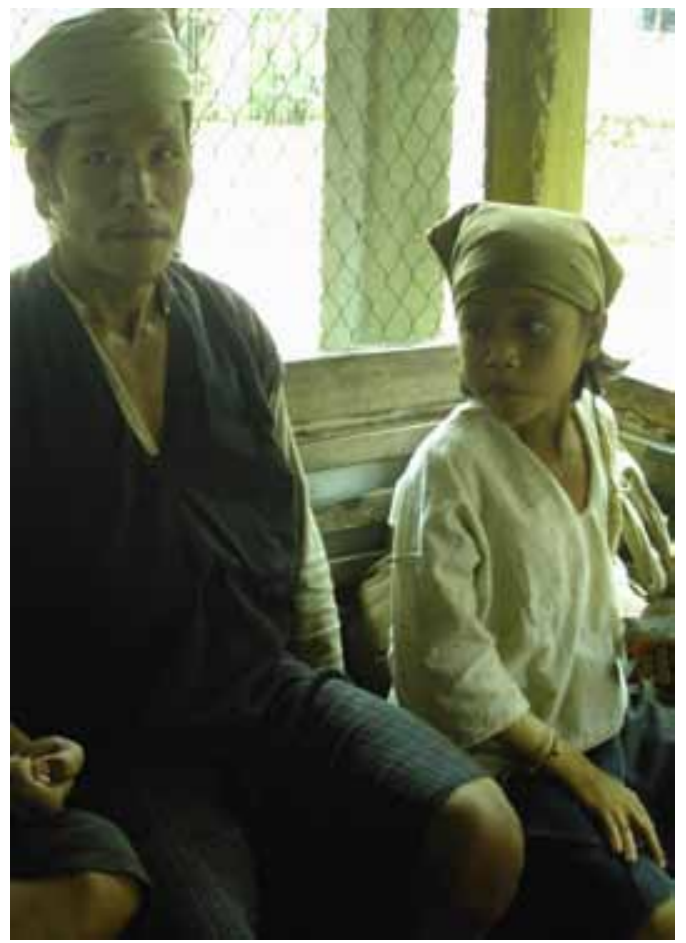

Gambar 1. Bapak dan anak dari masyarakat Baduy Dalam. 
kampung Kaduketug, Balimbing, dan Gajeboh. Kampung Kaduketug dipilih karena merupakan kampung Baduy yang letaknya berbatasan langsung dengan kampung non-Baduy sehingga interaksi dengan masyarakat bukan Baduy sangat tinggi di sini. Kampung Balimbing termasuk kampung baru, terletak lebih ke dalam wilayah Baduy, namun di sini terdapat "Posyandu" dan "Kader kesehatan dari Puskesmas" sehingga telah terjadi interaksi dengan pelayanan kesehatan modern. Kampung Gajeboh terletak jauh lebih ke dalam lagi dan merupakan kampung Baduy tua, dan di sini terdapat "paraji" atau dukun kampung terkenal yang wilayah kerjanya mencapai hingga dua belas kampung. Melalui penelitian ini diharapkan diketahui antara lain sistem dan tradisi asli pengobatan Baduy.

\section{PENGETAHUAN TRADISIONAL DAN KEARIFAN TENTANG PENGOBATAN}

Tidak banyak orang yang mengetahui secara benar apa itu pengetahuan tradisional. Dalam kaitan ini, Avonina (2006) dalam artikelnya berjudul “Apa yang dimaksud dengan pengetahuan tradisional" menjelaskan maksud dari istilah pengetahuan tradisional. Tidaklah mudah baik untuk memahami maupun untuk menjelaskan pengetahuan tradisional itu karena adanya perbedaan karakteristik dan bentuk pengetahuan itu dari daerah yang satu dengan yang lain dengan kebudayaannya masing-masing. Avonina (2006) mengajukan suatu penjelasan tentang pengetahuan tradisional yang bersifat luas. Penjelasannya ini merupakan upayanya untuk memudahkan dalam penyebutan mengenai suatu hal yang sama. Menurutnya, pengetahuan tradisional adalah segala sesuatu yang terkait dengan bentuk-bentuk tradisional, baik itu suatu kegiatan ataupun hasil suatu karya yang biasanya didasarkan pada suatu kebudayaan tertentu. Pengetahuan tradisional tersebut sebagian besar merupakan suatu karya yang telah mengalami perkembangan di masa lalu dan masih terdapat kemungkinan untuk mengalami perkembangan di masa yang akan datang, digunakan dan diwariskan secara turun temurun dari generasi ke generasi.

Mengenai kearifan lokal (local wisdom), Hadi (2006) menyatakan bahwa pada dasarnya dalam setiap komunitas masyarakat, termasuk komunitas masyarakat tradisional sekalipun, terdapat suatu proses untuk"menjadi pintar dan berpengetahuan". Hal itu berkaitan dengan adanya keinginan agar dapat mempertahankan dan melangsungkan kehidupan sehingga warga komunitas masyarakat secara spontan akan memikirkan cara-cara untuk melakukan dan/ atau menciptakan sesuatu, termasuk misalnya cara untuk membuat makanan dan cara untuk membuat peralatan yang diperlukan untuk mengolah sumber daya alam demi menjamin tersedianya bahan makan. Dalam proses tersebut suatu penemuan yang sangat berharga dapat terjadi tanpa disengaja. Mereka menemukan bahwa suatu jenis tanaman tertentu dapat menghasilkan buah yang dapat dimakan setelah dilakukan cara pengolahan tertentu; atau daun tertentu dapat menyembuhkan mereka dari sakit perut, sedang daun lain bisa mengobati demam; atau akar-akaran tertentu dapat menyembuhkan luka. Dengan demikian, mereka mengembangkan suatu sistem pengetahuan dan 
teknologi yang asli yang disebut sebagai suatu kearifan lokal. Lebih lanjut dikatakan Hadi (2006) bahwa kearifan lokal dipandang sangat bernilai dan mempunyai manfaat tersendiri dalam kehidupan masyarakat, setidaknya bagi masyarakat pemiliknya. Sistem tersebut dikembangkan karena adanya kebutuhan untuk menghayati, mempertahankan, dan melangsungkan hidup sesuai dengan situasi, kondisi, kemampuan, dan tata nilai yang dihayati di dalam masyarakat terkait. Dengan kata lain, kearifan lokal tersebut kemudian menjadi bagian dari cara hidup mereka yang arif, untuk memecahkan segala permasalahan hidup yang mereka hadapi. Berkat kearifan lokal itu, mereka dapat melangsungkan kehidupannya, bahkan dapat berkembang secara berkelanjutan.

Pengetahuan tradisional dan kearifan lokal itu antara lain mencakup pengobatan berbasis tanaman atau tumbuhan. Hidayat (2005) dalam bukunya Ramuan tradisional ala 12 etnis Indonesia mengisahkan bahwa tumbuh-tumbuhan telah digunakan oleh manusia sejak beribu tahun yang lalu untuk menjaga kesehatan dan mengobati berbagai penyakit. Dalam sejarah perkembangannya, tercatat tokoh-tokoh terkenal di dunia pengobatan yang berbasis tanaman, seperti Hippocrates (460-370 SM), Dioscorides (40-80 SM), Galenus (131-200 M), Avicenna (980-1037 M), dan Paracelsus (1493-1541 M).

E.Y.Sukandar dalam orasi ilmiah yang disampaikan pada Dies Natalis ITB pada tahun 2006 menguraikan bahwa bangsa Indonesia telah lama mengenal dan menggunakan tanaman berkhasiat obat sebagai salah satu upaya dalam menanggulangi masalah kesehatan. Pengetahuan tentang tanaman berkhasiat obat berdasar pada pengalaman dan keterampilan yang secara turun temurun telah diwariskan dari satu generasi ke generasi berikutnya. Penggunaan bahan alam sebagai obat tradisional di Indonesia telah dilakukan oleh nenek moyang sejak berabad-abad yang lalu terbukti antara lain dari adanya naskah lama pada daun lontar Husodo (Jawa), Serat Primbon Jampi (Jawa), Usada (Bali), dan Lontarak pabbura (Sulawesi Selatan). Dalam bentuk karya monumen, informasi sejenis diperoleh pada relief candi Borobudur yang menggambarkan orang sedang meracik obat (jamu) dengan tumbuhan sebagai bahan bakunya (Sukandar 2006).

Selain di Indonesia, pengobatan yang berbasis tanaman juga dapat ditemukan di negara-negara lain. Berbagai bangsa telah mengembangkannya sejak lama, di antaranya Cina, Jepang, Korea, Malaysia, India, suku Indian di Amerika, dan berbagai negara di Afrika. Bahkan, Cina terkenal sebagai "gudangnya" ramuan tradisional. Pengobatan seperti ini di Cina telah dilakukan sejak zaman Dinasti Ming, sekitar tahun 1368-1644. Pada zaman itu para tabib secara turun-temurun rajin mencatat berbagai resep berkhasiat obat yang mereka temukan. Kurang lebih ada sekitar 3.000 buku ramuan obat Cina yang sampai sekarang masih banyak digunakan. Pemerintah Cina pun mendukung perkembangan pengobatan dengan ramuan tradisional itu secara sungguh-sungguh (Redaksi Agromedia 2005).

Dalam buku Tumbuhan obat Indonesia; Penggunaan dan khasiatnya, yang disusun oleh Supriadi dkk. (2001), dinyatakan bahwa pengetahuan lokal 
dalam pemanfaatan tumbuhan/bahan alami untuk pengobatan umumnya dimiliki oleh masyarakat yang terutama berada di sekitar kawasan hutan. Pengetahuan tentang tumbuhan obat, mulai dari pengenalan jenis tumbuhan, bagian yang digunakan, cara pengolahan sampai dengan khasiat pengobatannya, merupakan kekayaan pengetahuan lokal dari masingmasing etnis dalam masyarakat setempat tersebut. Pengetahuan masyarakat tradisional tentang khasiat obat suatu tumbuhan untuk penyembuhan suatu penyakit pada umumnya didasarkan pada isyarat alam atau perilaku binatang. Sebagai contoh, helai daun yang berbentuk hati mempunyai petunjuk dapat menyembuhkan penyakit hati; bagian tanaman yang berwarna kuning seperti kunyit dan temulawak mempunyai petunjuk dapat menyembuhkan penyakit kuning; binatang sakit yang makan jenis tumbuhan tertentu memberi petunjuk bahwa tumbuhan tersebut berkhasiat obat (Supriadi dkk. 2001: ix-xi).

Berasal dari pengetahuan masyarakat etnis setempat telah diketahui beberapa jenis tumbuhan dalam hutan tropika berkhasiat obat yang sangat populer. Jenis tumbuhan tersebut antara lain pulai (Alstonia scholaris) dari keluarga Apocynaceae dan pasak bumi (Eurycoma longifolia) dari keluarga Simaroubaceae. Kedua jenis tumbuhan ini telah digunakan untuk mengobati penyakit malaria oleh 15 dari 45 etnis yang diamati. Dari hasil penelitian ilmiah diperoleh bahwa pasak bumi adalah tumbuhan liar yang banyak dijumpai di hutan-hutan Sumatra dan Kalimantan yang mengandung senyawa bioaktif "eurycomanone" yang efektif utuk menyembuhkan penyakit malaria. Hal ini memperkuat pengetahuan lokal dari masyarakat tersebut bahwa pasak bumi cocok digunakan sebagai obat malaria. Dari beberapa contoh yang dikemukakan tersebut, Supriadi menyimpulkan bahwa khazanah pengetahuan lokal dapat dipergunakan sebagai landasan sumber untuk membantu pengembangan obat modern yang berasal dari tumbuhan obat lainnya (Supriadi dkk. 2001: xii).

Dewasa ini pengobatan berbasis tanaman telah diterima secara luas hampir di seluruh negara di dunia. Menurut World Health Organization (WHO), negara-negara di Afrika, Asia, dan Amerika Latin menggunakan obat berbasis tanaman (herbal) sebagai pelengkap pengobatan primer yang mereka terima. Bahkan di Afrika, sebanyak $80 \%$ dari populasi menggunakan obat herbal untuk pengobatan primer. WHO juga mendukung pelbagai upaya peningkatan keamanan penggunaan obat tradisional tersebut (WHO 2003). Hal-hal yang menjadi pendorong terjadinya peningkatan penggunaan obat berbasis tanaman di negara maju adalah antara lain selain karena adanya pencarian alternatif pengobatan lain karena hasil yang dicapai pengobatan modern dianggap tidak selalu memuaskan, juga karena reputasi pengobatan tradisional yang semakin membaik di seluruh dunia (Sukandar 2006).

\section{GAMBARAN UMUM MASYARAKAT BADUY}

Salah satu masyarakat di Indonesia yang masih memiliki potensi praktek pengobatan tradisional adalah Baduy. Masyarakat Baduy berada pada wilayah sebelah barat Jawa Barat. Secara administratif, wilayah Baduy sekarang 
termasuk dalam Desa Kanekes, Kecamatan Leuwidamar, Kabupaten Lebak, Propinsi Banten, dengan luas 5.101,85 hektar. Luas wilayah sekarang ini lebih kecil daripada masa-masa sebelumnya. Menurut laporan A.J. Spaan (1867, Over de rechten van den Inlander op den grond) dan B. van Tricht (1929, The Badoejs in South-Bantam (Java)), yang dikutip Garna (1993) pada akhir abad kedelapan belas, wilayah Baduy terbentang mulai dari Kecamatan Leuwidamar sekarang sampai ke pantai selatan. Batas desa seperti yang ada sekarang ini dibuat pada permulaan abad kedua puluh bersamaan dengan pembukaan perkebunan karet di desa Leuwidamar dan sekitarnya. Namun, menurut perkiraan Garna, luas wilayah Baduy dahulunya meliputi beberapa kecamatan seperti Muncang, Sajira, Cimarga, Maja, Bojongmanik, dan Leuwidamar (Garna 1993: 124-135). Mengenai asal-usul masyarakat Baduy antara lain didasarkan pada laporan C.L. Blume (1823, Beschrijving van eenige gewassen, waargenomen op eenen togt naar den Salak, in den jare 1822) ketika melakukan ekspedisi botani ke daerah tersebut pada tahun 1822. Cuplikan tulisannya di dalam Garna (1993: 144) sebagai berikut.

\begin{abstract}
"[...] dipangkuan sebuah rangkaian pegunungan, yang menjulang tinggi di Kerajaan Bantam di Jawa Barat [...] kami mendapatkan beberapa kampung pribumi, yang dengan sengaja bersembunyi dari penglihatan orang-orang luar [...] Di sebelah barat dan di selatan gunung ini [...] yang tidak dimasuki oleh ekspedisi Hasanudin [...] dalam kegelapan hutan yang lebat, mereka masih dapat memuja para dewa mereka selama berabad-abad [...]".
\end{abstract}

Menurut Blume, komunitas Baduy ini berasal Kerajaan Sunda Kuno, yaitu Pajajaran, yang bersembunyi ketika kerajaan ini runtuh pada awal abad ketujuh belas, menyusul bergeloranya ajaran Islam dari Kerajaan Banten (Garna 1993: 144).

Van Tricht, seorang dokter yang pernah melakukan riset kesehatan pada tahun 1928, menyangkal teori yang menyatakan bahwa komunitas Baduy berasal dari Kerajaan Pajajaran. Menurut dia, mereka adalah penduduk asli dari daerah tersebut yang mempunyai daya tolak yang kuat terhadap pengaruh luar (Garna 1993: 146). Orang Baduy sendiri pun menolak jika dikatakan bahwa mereka berasal dari orang-orang pelarian Kerajaan Pajajaran. Menurut Danasasmita dan Djatisunda (1986: 4-5) orang Baduy adalah penduduk setempat yang kawasannya dijadikan mandala (kawasan yang suci) secara resmi oleh raja, karena penduduknya berkewajiban memelihara kabuyutan (tempat pemujaan leluhur atau nenek moyang). Kabuyutan di daerah ini dikenal dengan kabuyutan Jati Sunda atau Sunda Asli atau Sunda Wiwitan (wiwitan = asli, asal, pokok, jati). Oleh karena itulah agama asli mereka pun diberi nama Sunda Wiwitan.

Sebutan Orang Baduy atau Urang Baduy awalnya bukanlah berasal dari mereka sendiri. Istilah Baduy diberikan oleh orang-orang di luar wilayah Baduy, dan kemudian digunakan dalam laporan-laporan etnografi pertama yang disusun oleh orang-orang Belanda. Dalam laporan para peneliti Belanda seperti W.R. Hoëvell (1845), J. Jacob dan J.J. Meijer (1891), dan C.M. Pleyte 
(1909), masyarakat itu disebut dengan Badoe'i, Badoei, dan Badoewi. Dari laporan-laporan inilah diturunkan sebutan Baduy. Bahkan, pada tahun 1980, ketika Kartu Tanda Penduduk (KTP) diperkenalkan di daerah itu, hampir semua penduduk tidak menolak disebut sebagai Orang Baduy. Selain itu, sebutan diri yang biasa mereka gunakan adalah Urang Kanekes. Mereka biasa pula menyebut asal dan wilayah kampung mereka seperti Urang Cibeo (nama salah satu kampung), Urang Tangtu (Baduy Dalam), dan Urang Panamping (Baduy Luar) (Garna 1993: 120).

Secara umum, masyarakat Baduy terbagi menjadi tiga bagian, yaitu tangtu, panamping, dan dangka. Tangtu dan panamping berada pada wilayah desa Kanekes, sedangkan dangka terdapat di luar desa Kanekes. Bila dilihat berdasarkan kesucian dan ketaatannya kepada adat, tangtu lebih tinggi daripada panamping, dan panamping itu sendiri lebih tinggi daripada dangka. Namun, pembagian yang sering digunakan adalah tangtu, merujuk pada masyarakat Baduy Dalam, sedangkan panamping dan dangka merujuk pada masyarakat Baduy Luar (Permana 2006: 27-28). Tangtu diartikan sebagai tempat dan sekaligus pendahulu atau cikal bakal (pokok) baik dalam arti pangkal keturunan maupun pendiri pemukiman. Di wilayah Baduy ini terdapat tiga buah pemukiman (kampung) tangtu, yaitu (1) Cikeusik atau disebut pula Tangtu Pada Ageung, (2) Cibeo atau disebut pula Tangtu Parahiyang, dan (3) Cikartawana atau disebut pula Tangtu Kujang. Ketiga kampung tersebut sering pula disebut sebagai telu tangtu (tiga tangtu). Masyarakat tangtu ini sering pula dinamakan Baduy Jero, Urang Kajeroan, atau Baduy Dalam. Panamping menurut orang Baduy berasal dari kata "tamping" yang berarti 'buang'; jadi panamping berarti 'pembuangan', yakni tempat bagi orang tangtu yang dibuang atau dikeluarkan karena melanggar adat. Adapun, dangka berarti 'rangka' atau 'kotor', juga sebagai tempat pembuangan warga Baduy yang melanggar adat (Danasasmita dan Djatisunda 1986: 11-12).

Pada masyarakat Baduy ini dikenal dua sistem pemerintahan, yaitu sistem nasional dan sistem tradisional (adat). Dalam sistem nasional, masyarakat Baduy termasuk dalam wilayah Desa Kanekes, Kecamatan Leuwidamar, Kabupaten Lebak, Propinsi Banten. Seperti halnya dengan daerah lain di Indonesia, setiap desa terdiri atas sejumlah kampung. Di daerah Baduy kampung-kampung tersebut terbagi menjadi kampung tangtu, kampung panamping, dan kampung dangka. Kecuali kampung tangtu, terdapat juga RK (Rukun Kampung), yang disebut kokolotan lembur. Desa Kanekes ini dipimpin oleh kepala desa, yang disebut Jaro Pamarentah (dahulu disebut Jaro Warega, lalu pada zaman kolonial disebut Jaro Gubernemen). Seperti kepala desa atau lurah di desa lain, ia berada di bawah camat, kecuali untuk urusan adat yang tunduk kepada kepala pemerintahan tradisional (adat), yang disebut puun. Uniknya, apabila kepala desa di tempat lain dipilih oleh warga, untuk Kanekes kepala desanya ditunjuk oleh puun, baru kemudian diajukan kepada bupati (melalui camat) untuk kemudian dikukuhkan sebagai kepala desa. Pada tahun 2008 yang menjabat sebagai Jaro Pamarentah adalah Jaro Daina (53 tahun).

Sementara itu, secara tradisional pemerintahan pada masyarakat Baduy 
bercorak kesukuan yang disebut kapuunan, karena puun menjadi pimpinan tertinggi. Puun di wilayah Baduy ini ada tiga orang, masing-masing puun Cikeusik, puun Cibeo, dan puun Cikartawana. Puun-puun ini merupakan "tritunggal", karena selain berkuasa di wilayahnya masing- masing, juga secara bersama-sama memegang kekuasaan pemerintah tradisional masyarakat Baduy. Walaupun merupakan satu kesatuan kekuatan, ketiga puun tersebut juga mempunyai tugas dan wewenang yang berlainan. Wewenang kapuunan Cikeusik menyangkut urusan keagamaan dan ketua pengadilan adat, yang menentukan pelaksanaan upacara-upacara (seren tahun, kawalu, dan seba) ${ }^{2}$, dan memutuskan hukuman bagi para pelanggar adat. Wewenang kapuunan Cibeo menyangkut pelayanan baik kepada warga maupun tamu yang datang ke kawasan Baduy, termasuk mengurus administrasi ketertiban wilayah, pelintasan batas, dan hubungan dengan daerah luar. Sedangkan wewenang kapuunan Cikartawana menyangkut urusan pembinaan warga, kesejahteraan, keamanan, atau sebagai badan pelaksana yang langsung memonitor di lapangan permasalahan yang berhubungan dengan kawasan Baduy.

Sebagai suatu desa, Baduy atau Kanekes terdiri atas beberapa kampung yang terbagi menjadi dua kelompok besar, yaitu Baduy Dalam dan Baduy Luar, seperti yang telah dijelaskan sebelumnya. Jika kampung yang termasuk dalam kelompok Baduy Dalam meliputi kampung Cibeo, Cikartawana, dan Cikeusik, maka kampung yang termasuk dalam kelompok Baduy Luar berjumlah lebih dari 50 kampung (Permana 2006).

Di dalam Permana (2006) disebutkan bahwa data demografi tentang orang Baduy pertama kali tercatat pada tahun 1888. Menurut data itu, jumlah penduduk Baduy adalah 291 orang yang menempati sepuluh kampung. Namun, pada tahun berikutnya dilaporkan data jumlah penduduk Baduy meningkat menjadi 1.407 orang yang tinggal di 26 kampung. Pada awal abad kedua puluh, sekitar tahun 1908, penduduk Baduy dilaporkan berjumlah 1.547 orang. Sedangkan dua puluh tahun kemudian, menurut laporan B. van Tricht pada tahun 1929, jumlah penduduk dilaporkan sedikit berkurang menjadi 1.521 orang. Seabad kemudian, berdasarkan perhitungan terakhir (2004/2005) yang dihimpun dari data Puskesmas dan Kantor Desa Kanekes, penduduk Baduy tersebut terdiri atas 3.697 pria dan 3.835 wanita (Permana 2006: 23).

Berdasarkan kepercayaannya, orang Baduy sangat menghormati leluhur atau nenek moyang. Pusat pemujaan mereka berada di puncak gunung yang disebut Sasaka Domas atau Sasaka Pusaka Buana. Objek pemujaan ini pada dasarnya merupakan sisa kompleks peninggalan megalitik berupa bangunan berundak atau berteras-teras dengan sejumlah menhir dan arca di atasnya. Inilah yang dianggap oleh orang Baduy sebagai tempat berkumpulnya para

\footnotetext{
2 Seren taun adalah upacara syukuran kepada Yang Maha Kuasa atas kemurahan dan limpahan rezeki berupa hasil bumi (perladangan). Yang dimaksud dengan kawalu adalah upacara "kembalinya" padi dari ladang (huma) ke lumbung (leuit), yang dilakukan pada bulan katiga, kapat, dan kalima menurut kalender Baduy. Selama masa kawalu, wilayah Baduy tertutup bagi tamu atau pendatang. Seba adalah upacara persembahan hasil perladangan kepada pimpinan wilayah setempat. Sekarang hasil perladangan itu dipersembahkan kepada Bupati Lebak di Rangkasbitung, dan kepada Gubernur Banten di Serang.
} 
karuhun atau nenek moyang (Permana 2006: 38). Keyakinan mereka, seperti telah dijelaskan sebelumnya, disebut dengan Sunda Wiwitan atau agama Sunda Wiwitan. Orientasi, konsep, dan kegiatan keagamaan ditujukan kepada pikukuh (ketentuan adat mutlak) agar supaya orang hidup menurut alur itu dan menyejahterakan kehidupan Baduy dan dunia ramai. Garna (1988: 53-54; 1993: 139) melaporkan bahwa orang Baduy berasal dari hierarki tua, sedangkan dunia ramai (di luar Baduy) merupakan keturunan yang lebih muda. Orang Baduy bertugas menyejahterakan dunia melalui tapa (perbuatan, bekerja) dan pikukuh. Bila wilayah Baduy, yang dianggap sebagai pancer bumi (inti jagat atau pusat dunia), selalu terpelihara dengan baik, maka seluruh kehidupan akan aman sejahtera. Konsep keagamaan dan adat terpenting yang menjadi inti pikukuh Baduy adalah "tanpa perubahan apa pun", seperti tertuang dalam ungkapan sebagai berikut: lojor teu meunang dipotong, pendek teu meunang disambung yang berarti " panjang tak boleh dipotong, pendek tak boleh disambung".

\section{PENGOBATAN TRADISIONAL BADUY}

Dalam kaitannya dengan masalah kesehatan, setiap masyarakat di muka bumi ini secara budaya mempersepsikan dan mendefinisikannya secara berbedabeda. Menurut konsep masyarakat Baduy, seseorang dikatakan dalam keadaan sakit adalah apabila sesuatu yang dideritanya itu tidak dapat diobati sendiri dan orang itu tidak dapat beraktivitas sehari-hari seperti biasanya. Jika seseorang misalnya menderita batuk, gatal-gatal, masuk angin, atau pilek, belumlah dapat dikatakan sakit karena yang bersangkutan dikatakan masih dapat beraktivitas. Selain itu, seseorang dikatakan sakit, apabila keadaan itu dinyatakan oleh paraji (dukun) atau kokolot lembur (tetua kampung). Dari pengertian tentang "sakit" di atas, ada dua hal yang penting, yakni "jika tidak dapat sembuh sendiri" dan "dinyatakan sakit oleh paraji atau kokolot". Pernyataan "jika tidak dapat sembuh sendiri" memiliki konsekuensi positif bahwa masyarakat Baduy selalu berusaha untuk mencari dan mengatasi gangguan ketidaknyamanan dalam dirinya. Umumnya mereka memanfaatkan sumber daya alam sekitarnya, khususnya tanaman yang diyakini memiliki khasiat menghilangkan gangguan kesehatannya. Hal positif lainnya adalah masyarakat Baduy berusaha mempertahankan pengetahuan dan kearifan lokalnya untuk pengobatan penyakit. Sementara itu, dari pernyataan "dinyatakan sakit oleh paraji atau kokolot" juga memiliki konsekuensi positif bahwa masyarakat Baduy masih tetap mempertahankan keberadaan dan fungsi adat dan kelembagaan formalnya, khususnya yang berkaitan dengan masalah kesehatan. Istilah sakit dalam bahasa Baduy sering disebut dengan nyeri, sedangkan istilah penyakit digunakan panyakit. Orang yang sedang sakit disebut dengan istilah gering, sedangkan orang yang menderita atau mengidap penyakit dinamakan panyakitan. Orang yang membawa atau menularkan penyakit dalam bahasa Baduy disebut nepaan. Adapun orang yang sehat atau tidak sakit disebut jagjag, sedangkan orang yang membantu menyembuhkan penyakit disebut paraji dan dukun. Istilah sakit atau nyeri 
terdapat dalam beberapa kategori lagi, misalnya muriang, nyeri sirah, nyeri teu puguh, nyeri teu cagur, leuleus, asup angin, dan lileur untuk menyatakan kondisi badan yang panas, sakit kepala, tidak enak badan, kurang sehat, badan lemas, masuk angin, dan batuk-batuk. Sebaliknya, orang yang sehat atau jagjag juga terbagi dalam beberapa sebutan lagi, seperti sangat sehat atau segar bugar (jagjag waringkas) dan tangkas atau gesit (jalingeur).

Pengetahuan mengenai penyakit dan pengobatannya bagi masyarakat Baduy termasuk warisan tradisional yang diturunkan dari generasi ke generasi. Sejak kecil sebagian mereka telah diajarkan oleh orang tua mereka yang memiliki pengetahuan memanfaatkan tanaman-tanaman tertentu di sekitarnya untuk mengobati berbagai penyakit. Tanaman-tanaman tersebut banyak dan dapat diperoleh di hutan, sekitar ladang, atau sepanjang jalan menuju hutan atau ladang. Beberapa contoh tanaman yang biasa digunakan sehari-hari oleh masyarakat Baduy untuk mengobati penyakit ringan adalah: daun jambu biji untuk mengobati sakit perut, daun jampang pahit untuk mengobati luka, tanaman capeuk untuk menghilangkan pegal-pegal, daun harendong untuk mengobati sakit gigi, dan kulit pohon terep untuk menghilangkan gatal-gatal pada kulit.

Dalam khazanah penyembuh tradisional Baduy dikenal adanya paraji (dukun beranak), panghulu (dukun yang khusus mengurus orang meninggal), bengkong jalu (dukun sunat untuk laki-laki), dan bengkong bikang (dukun sunat untuk perempuan). Khususnya paraji, dalam prakteknya dia tidak hanya mengurus proses persalinan, tetapi juga membantu mulai dari sebelum sampai sesudah melahirkan. Pada proses sebelum melahirkan, misalnya, paraji membantu mengurut perut ibu hamil agar posisi janin baik dan benar, atau memberikan ramuan-ramuan agar kehamilannya baik dan lancar ketika persalinan. Sedangkan untuk sesudah melahirkan, paraji membantu penyembuhan ibu selama masa nifas dan jika ada gangguan selama menyusui, serta membantu perawatan bayi hingga lepas tali pusar. Paraji juga sering dianggap sebagai dukun semua penyakit, termasuk penyakit karena gangguan makhluk halus. Bantuan yang diberikan biasanya berupa informasi tanaman-tanaman yang dapat dimanfaatkan sebagai obat, serta cara mengolah dan menggunakannya. Selain tetap menggunakan ramuan tanaman dan ramuan lain, pengobatan yang dilakukan oleh penyembuhpenyembuh tradisional tersebut juga disertai dengan mantra-mantra atau jampi-jampi tertentu. Karena masih kuatnya kepercayaan pada pengobatan tradisional, maka pada prakteknya Puskesmas yang sejak tahun 1980-an didirikan di perbatasan kampung Baduy jarang dikunjungi oleh warga Baduy, baik Baduy Luar apalagi Baduy Dalam. Sebagian warga Baduy yang terpaksa memanfaatkan jasa dokter atau Puskesmas adalah orang yang menderita luka robek yang besar atau menderita penyakit berat yang tidak kunjung sembuh oleh penyembuh tradisional. Sering pula terjadi, ada anggapan agar cepat sembuh pengobatan luka (yang dijahit) oleh dokter dikombinasikan dengan tanaman obat tradisional. 
Mengenai tanaman berkhasiat obat, sebenarnya sangat banyak jenis tanaman yang dapat dimanfaatkan. Hanya saja seiring dengan perjalanan waktu dan dinamika dalam perikehidupan masyarakat, maka hanya sekitar 60-an jenis tanaman saja yang masih dikenal dan biasa digunakan oleh masyarakat Baduy sebagai obat. Dari sekian banyak jenis tanaman itu, tanaman yang paling sering digunakan sebagai obat adalah daun aceh (rambutan $=$ Nephelium lappaceum $\mathrm{L}$.), , cecendet $($ ciplukan $=$ Physalis peruviana L.), cangkudu (mengkudu = Morinda citrifolia L.), cikur (kencur = Kaempferia galanga L.), harendong (senggani = Melastoma malabathicum L.), jahe (jahe = Zingiber officinale Rosc.), jukut eurih (alang-alang = Imperata cylindrica (L.) Beauv.), jukut wisa (jarong $=$ Achyranthes aspera L.), kadaka (sisik naga $=$ Drymoglossum piloselloides (L.) Presl.), laja goah (lengkuas gajah = Alpinia galanga (L.) Willd.), lame putih (pulai = Alstonia scholaris L.), lempuyang emprit (lempuyang pahit $=$ Zingiber amaricans), panglay (bangle = Zingiber pupureum), sirsak (sirsak = Annona muricata L.), dan singugu (senggugu = Clerodendron serrature). Jenis-jenis tanaman ini banyak digunakan dalam pengobatan penyakit yang sering diderita oleh warga masyarakat Baduy seperti panas/ demam/meriang, batuk, sakit perut/diare, sakit gigi, pusing, pegal linu/ encok/nyeri otot, luka/borok, dan lemas/kurang bertenaga.

Untuk mengobati penyakit panas/demam/meriang masyarakat Baduy biasanya menggunakan: (1) minuman dari rebusan air daun dadap, jukut tiis, dan daun aceh, atau (2) minuman dari air seduhan remasan daun kaca piring dan daun sirsak. Untuk penyakit batuk diobati dengan: (1) minuman dari rebusan bunga calincing (Oxalis corniculata L.), (2) minuman dari air rebusan tanaman utuh cecendet, (3) air saringan jahe parut/tumbuk, dan (4) air saringan cikur parut/tumbuk. Untuk penyakit sakit perut/diare mereka menggunakan: (1) minuman dari air rebusan tanaman utuh cecendet, (2) minuman air rebusan daun muda harendong, (3) daun jambu klutuk yang dimakan mentah, (4) minuman air rebusan kulit pohon lame putih, dan (5) minuman seduhan lempuyang. Untuk penyakit gigi digunakan: (1) tetesan getah angsana (atau sonokembang, Pterocarpus indicus Willd.) pada gigi yang sakit dan (2) daun kadaka yang digigitkan tepat pada gigi yang sakit. Untuk penyakit pusing/sakit kepala digunakan: (1) tetesan air perasan bunga jukut kakacangan, (2) minuman seduhan laja goah, (3) minuman air rebusan kulit pohon lame putih, dan (4) minuman seduhan lempuyang. Untuk penyakit lemas/nyeri otot/encok biasanya menggunakan: (1) tumbukan jukut bau yang diborehkan pada bagian yang sakit, (2) minuman seduhan lempuyang, (3) pucuk daun senggugu yang ditempelkan pada bagian yang sakit, (4) parutan atau tumbukan jahe yang dibalurkan pada bagian yang sakit. Untuk penyakit luka/borok digunakan: (1) remasan daun harendong yang ditempelkan pada bagian yang sakit dan (2) remasan jukut bau yang ditempelkan pada bagian yang sakit. Untuk penyakit lemas/kurang bertenaga mereka menggunakan: (1) minuman rebusan daun capeuk, (2) minuman rebusan umbi laja goah dan kulit pohon lame, dan (3) lalapan temu embek. 
Berbagai jenis tumbuhan yang digunakan untuk obat tersebut diperoleh di semak belukar sekitar kampung, ladang, atau hutan, dan jarang sekali tersedia di pekarangan rumah. Oleh karena itu, jika memerlukan tanaman untuk mengobati penyakit tertentu dengan menggunakan tumbuhan, biasanya masyarakat Baduy mencari di semak belukar sekitar kampung, ladang, atau di hutan. Permasalahan muncul ketika tanaman obat yang mendadak diperlukan tidak diperoleh di sekitar kampung, melainkan harus dicari di ladang atau di hutan. Padahal jarak antara pemukiman dan ladang atau hutan cukup jauh. Kalaupun dapat dicapai, kadang kala tanaman yang dimaksud tidak dijumpai, karena hutan semakin gundul akibat perluasan ladang.

Salah satu langkah yang dapat diusulkan menjadi jalan keluar untuk menghadapi permasalahan tersebut adalah misalnya dengan membuat kebun apotek hidup. Kebun apotek hidup tersebut berupa lahan yang di dalamnya ditanami tumbuh-tumbuhan yang diyakini dapat digunakan untuk mengobati berbagai macam penyakit. Kebun apotek tersebut sekurang-kurangnya dibuat di lingkungan pemukiman sehingga tanaman-tanaman berkhasiat obat mudah diperoleh karena tumbuh di lingkungan tempat tinggal. Jika terjadi keperluan mendadak untuk pertolongan kesehatan, tidak perlulah mencari tanaman obat jauh-jauh ke hutan. Manfaat lain kebun apotek hidup ini adalah kemungkinan dapat menurunkan pengetahuan dan kearifan lokal mengenai pengobatan tradisional berbasis tanaman ke generasi selanjutnya. Pengobatan yang selama ini sudah memudar kembali dikenal dan diingat. Khazanah pengetahuan tentang obat dan pengobatan berbasis tanaman pun dengan demikian makin bertambah. Masyarakat tradisional setempat pun dapat mengobati penyakit dengan menggunakan tanaman berkhasiat obat tanpa melanggar pantangan adat.

\section{PENUTUP}

Perikehidupan masyarakat Baduy diatur oleh pikukuh. Dalam pikukuh ini ada pernyataan yang berarti "panjang tidak boleh dipotong, pendek tidak boleh disambung". Maksudnya adalah bahwa sesuatu tidak boleh diubah, ditambah atau dikurangi tetapi harus diterima sebagaimana adanya. Pada masyarakat Baduy Dalam (tangtu) pikukuh ini masih diikuti secara kuat tetapi pada masyarakat Baduy Luar (panamping) aturan adat itu tidak diikuti secara ketat lagi. Dalam masyarakat ini pelanggaran pikukuh akan diberikan ganjaran adat dari puun sebagai pimpinan adat tertinggi dalam masyarakat Baduy. Dengan adanya pikukuh, budaya dan adat istiadat masyarakat Baduy, khususnya pada tangtu, selama ini terlindung dari pengaruh luar. Dalam kehidupan mereka sehari-hari kebutuhan dalam masyarakat dicukupi oleh kekayaan alam yang ada di lingkungannya. Demikian pula dengan kebutuhan pengobatan. Mereka memanfaatkan tanaman-tanaman yang tumbuh di sekitar untuk diramu menjadi obat-obat penyembuh penyakit sehari-hari. Pengetahuan pengobatan tradisional dengan tanaman ini sudah dimiliki sejak dahulu dan diwariskan dari generasi ke generasi. Dengan adanya pikukuh, khususnya pada tangtu, pengobatan dari luar yang "modern" sulit menembus masuk ke 
dalam masyarakat. Oleh karena itu, pengobatan tradisional sangatlah berperan dalam kehidupan masyarakat Baduy. Pengetahuan pengobatan ini diharapkan tetap dapat diwariskan turun temurun sehingga kebutuhan pemeliharaan kesehatan dalam masyarakat itu dapat dipenuhi tanpa harus melanggar adat karena seseorang menjalani pengobatan dari luar Baduy. Namun, tidak semua penyakit ditemukan obatnya dalam pengobatan tradisional. Untuk itu, perlulah diadakan penelitian tanaman-tanaman yang memiliki khasiat sebagai obat. Pengembangan pengetahuan pemanfaatan tanaman obat dan kearifan lokal yang sudah ada tentang pengobatan tradisional ini akan lebih dapat menjamin pemeliharaan kesehatan masyarakat Baduy serta budayanya.

\section{DAFTAR PUSTAKA}

Avonina, Sthefanny. 2006. "Apa yang dimaksud dengan pengetahuan tradisional?", Konvergensi IX (Oktober): 14-19.

Danasasmita, Saleh dan Djatisunda, Anis. 1986. Kehidupan masyarakat Kanekes. Bandung: Bagian Proyek Penelitian dan Pengkajian Kebudayaan Sunda (Sundanologi).

Garna, Judhistira. 1988. "Perubahan sosial budaya Baduy", di dalam: Nurhadi Rangkuti (red.), Orang Baduy dari inti jagat, hlm 47-55. Yogyakarta: Bentara Budaya, KOMPAS, Etnodata, Prosindo, Yayasan Budhi Dharma Pradesa.

Garna, Judistira. 1993. "Masyarakat Baduy di Banten", di dalam: Koentjaraningrat (red.), Masyarakat terasing di Indonesia, hlm. 120-152. Jakarta: Depsos RI, Dewan Nasional Indonesia untuk Kesejahteraan Sosial, dan Gramedia Pustaka Utama.

Hadi, A.C Sungkana. 2006. “Melestarikan kearifan masyarakat tradisional (Indigenous Knowledge)", Buletin Perpustakaan dan Informasi Bogor (Juni): 27-32.

Hidayat, Syamsul. 2005. Ramuan tradisional ala 12 etnis Indonesia. Jakarta: Penebar Swadaya.

Iskandar, Johan. 1992. Ekologi perladangan di Indonesia; Studi kasus dari daerah Baduy, Banten Selatan, Jawa Barat. Jakarta: Djambatan.

Permana, R. Cecep Eka. 2006. Tata ruang masyarakat Baduy. Jakarta: Wedatama Widya Sastra.

Purnomohadi, Srihartiningsih. 1990. "Sistem Interaksi sosial-ekonomi dan pengelolaan sumber daya alam oleh masyarakat Badui di Desa Kanekes, Banten Selatan". Tesis Magister, Institut Pertanian Bogor, Bogor.

Redaksi Agromedia. 2005. Ramuan tradisional untuk mengatasi aneka penyakit. Jakarta: AgroMedia Pustaka.

Sukandar E Y, 2006. "Tren dan paradigma dunia farmasi, Industri-KlinikTeknologi Kesehatan". Orasi ilmiah Dies Natalis Institut Teknologi Bandung. (Http://itb.ac.id/focus/ focus_file / orasi-ilmiah-dies-45.pdf), diakses Januari 2006.

Supriadi dkk. 2001. Tumbuhan obat Indonesia; Penggunaan dan khasiatnya. Jakarta: Pustaka Populer Obor. 
World Health Organization (WHO). 2003. "Traditional medicine", (http:// www.who.int/mediacentre/factsheets/fs134/en/), diakses Januari 2006. 